\title{
ON CRITICAL ZONE OF THE OPTOKINETIC NYSTAGMUS
}

By

HIROYUK MOTOHASHI M.D.

\author{
From the Department of Otolaryngology (Head: Prof. M.HINOKI M.D.) and the \\ Department of Hygine and Publichealth (Head: Prof. M.UEMATSU M.D.) \\ Ire'ate Medical College
}

The present work was designed to elucidate a frequency of optokinetic nystagmus in normal subjects.

Five healthy adult men and five women with normal vestibular function were examined with regard to horizontal and vertical nystygmus by rotating the optic cylinder, which was rotated for 180 seconds with angular accereration $1 \% \mathrm{sec}^{2}$. In both of horizontal and vertical nystagmus, the frequencies of nystagmus reach at the maximum value between $40 \% / \mathrm{sec}$ and $100 \% \mathrm{sec}$, and then, maintain this level or decrease gradually.

By analysing the frequency obtained, the eqation of critical ellipse for the horizontal nystagmus or for the vertical (downwords or upwords) nystagmus in any subject was made.

According to the author's opinion, it seems to be useful for the examination of the eqilibrium function of patients to survey horizontal and vertical nystagmus by rotating the optic cylinder and to evaluate the result by putting the obtained data on the patient into the above-mentioned formula.

\section{視性眼振検査の規準值に関する研究}

\section{岩手医科大学耳鼻咽喉科学教室（主任：檜 学教授） \\ 岩手医科大学公衆衛生学教室 (主任：植松 稳教授)}

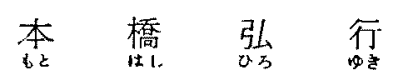

目次

1) はしぬに

2) 観 察対 象

3) 視刺战负荷装置

4）腿振記録装圆とその記䟿法

5) 視性眼振钼察方法

6) 眼振の测定

7) 㓋察成鈢

i) 視性水平性腿振の觀察

ii）視生整直性眼振の観察

a) 在傾頭位に和ける観察

b）右傾頭位に扣ける観察

8）热却榇円面による箖却检定

$\begin{array}{rrr}\text { 9) 症 } & \text { 例 } \\ \text { 10) 考 } & \text { 案 } \\ \text { 11) む す } 20\end{array}$

1)はじめに

視覚が身体平衡の維持必要なことは，古くより知ら れている，平衡反射の一つである視性眼振が，最近よう やく，ヒトの平衡機能検查法として取り上げられつつあ ることは，当を得た試みと考点られる。しかし、こ扎ま での文献を展望してみると，視珄水平性眼振の検索は盛 えに行なわれているが，垂直性眼振の跨究は少なく，特 に，後者の眼振を臨休的に応用し，盿最，平凘失調の分 析に系統的に資せんとした報告はほとんどみられない。 さて，ヒトの生活をみるに，その回転運動は，多くは 
水平面上で身体長軸を軸として行なわれるものであり， その際受ける視刺㦸は, 水平面上で左から右, または右 から左への水平性視刺㦸が多い。これに比し, 矢状面上 での頭部または身体運動に際して受ける上から下，また は下から上への垂直性視刺战は, 前者に比すると比較的 少ない,したがつて, ヒトにあつても, 水平泩眼振を成 立せしむべき視刺战と垂直性眼振を惹起するそれとで は, これらに対する生体の反応は，身体平滇の点からか なり異なつた様相を呈するもののようである。したがつ て，ヒトの平衡を分析する場合にも，ヒトが日常上く遭 遇する水平性視刺战を使用するのみならず，比較的遭遇 することの少い垂直性視刺㦸を用いて潜在性の視器系の 平衡失調をより明膫に表出しよう，とする試みもなされ てよいであろう.そして，われわれが胘㫾症の患者を問 診する場合, 視刺㦸により眩最が誘発される，と訴える 例をしぱしば認めるが, この際, 視刺㦸の方向の相異に より誘発される矓最の度合が異なる，と答える場合もあ る. このように考えると, 視性眼振の検査には, 従来の ように水平性眼振を検査するに留めないで, 同時に垂直 性眼振をも検查することが妥当のように思われる。な お，視刺㦸を負荷する場合，これまで筆者1)がヒトおよ び動物について実験した成績に爁み，ヒトの視性平衡を 視性眼振の点より究明する際には, 等速度視刺晖より加 速度視刺㦸を負荷し, 漸次增加する視刺㦸に視器がいか に対応していくか，を検討することがより合理的と考光 るので, 以下述べる検査には加速度視刺㦸を加えた。

また，従来加速度視刺战による水平性眼振扣よび垂值 性眼振の正常域值を統計学的に詳細に検討したものは少 なく，臨床的応用にすこぶる不便を感じていた，本論文 では, 得られた成績を統計学的に処理し, 臨床応用への 道をさらに開いた。

\section{2) 観察対象}

前庭機能検査を行ない, 迷路機能に異常を認めない正 常成人 10 人を観察の対象とした.

\section{3）視剌戟負荷装置}

視刺战負荷装置として, 四1 亿示寸上らに, 直径 $2 \mathrm{~m}$, 高さ $2 \mathrm{~m}$ の白布製円筒を用いた，この円筒の内面には， 幅 $4 \mathrm{~cm}$ の黒い縦線 15 本か゚等間隆に附してある，円筒 は電気で回転され， controllng panel により $0.5^{\circ} / \mathrm{sec}^{2}$ より $6 \% / \mathrm{sec}^{2}$ までの角加速度が $0.5^{\circ} / \mathrm{sec}^{2}$ 区分で加えら れるよら作製され，また，各速度の等速度回転をも負荷 しらるごとく設計されている．かつ，その回転方向も右 またに左に自由に変換できるように仕組まれている。な
図 1 電動式視性大円筒 （一部を開き内部を示す）

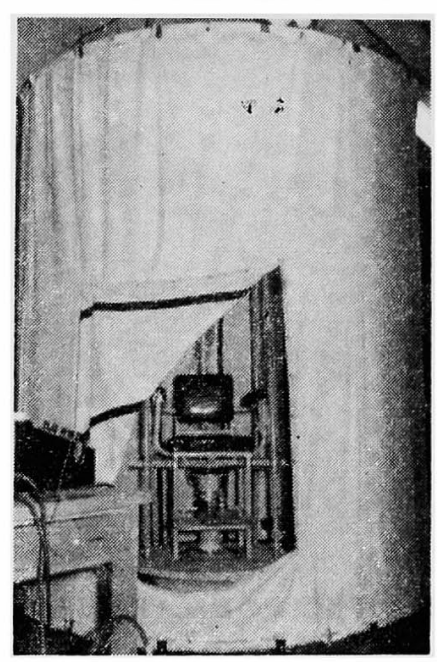

お，図1では，円简の一部を開いて内面を示してある が，視刺㦸負荷時にはこれを閉ざして用いることは云う までもない。

\section{4）眼振記録装置とその記録法}

眼振記録装置は三栄測器株式会社製 N-G 203 型万能 記録装置 (2 channel) を用いた，電極は平板銀電極を 使用した. 水平性眼振記録の場合には前額部および左右 両外眼角部に電極を置き，垂直性眼振記録の場合には右 眼の外眼角部, および上下眼瞼よりそれぞれ $2.0 \mathrm{~cm}$ 離し た篔処に電極を置いた。なお，水平性眼振記録時の前額 部の電極拉よび垂直性眼振記録時の外眼角部の電極はア ース電極である.

\section{5） 視性眼振観察方法}

視性円筒の中央に被検者を㥓座させ，円筒の黒い縦線 を注視するごとくあらかじめ指示する．視刺㦸は次のご とく加える、すなわち，視性円简を初速○より $1 \% / \mathrm{sec}^{2}$ の角加速度にて回転し角速度 $180^{\circ} / \mathrm{sec}$ に至らしめ, こ の速度に達すると被検者に閉眼を命じ，視刺战を遮断す ろ. 視性水平性腿振観察の場合には正頭位で㥓座させ, 頭は固定することなく視刺战を上述のごとく加えた（図 2). 視性垂直性眼振観察の場合には，頸部をまげさせて 頭部を椅子に取り付けた支持台上に置かせ, 眼窩縦軸が 水平面とほぼ平行になるよう位置せしめた（図3）. か くのごとく操作すると, 円筒を左または右に回枟するこ とにより眼简縱軸に平行する眼振，すなわち上下への垂 直性眼振が得られる。しかして垂直性眼振観察の場合に 


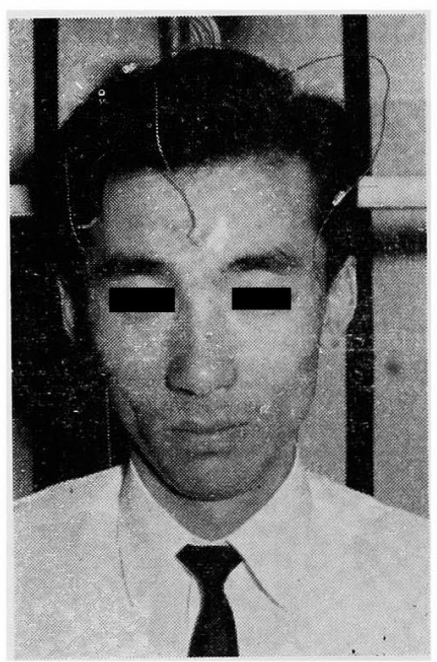

図 2 水平性眼振の観察 (ENG装着)

は，左傾頭位，右傾頭位それぞれについて円筒を右およ び左に回して観察した.すなわち計 4 回の钼察を行なつ ている.これに対して水平性眼振の観察は円筒を右打よ び左に各 1 回す゚つ, 計 2 回回転し観察を行なつている.

\section{6) 眼振の測定}

眼振電計は眼振の原波形々微分波形を同時に記録し, その paper speed は每秒 $0.5 \mathrm{~cm}$ とした. また, 水平 性眼振記録の場合, 上方への spike は右への眼振を, 下方への spike は左への眼振を示すごとく設計した. 垂直性眼振記録の場合はいずれも右眼で測定され，眼窩 上縁に向かつて速期を有する眼振を発来した際には上方 への spike が, 眼窩下縁に向かつて 速期を有する眼振 を発来した際には下方への spike が出現するよう設定 した．眼振の変動を表示する際には，180 秒間の視刺晖 負荷中に出現した眼振を $20 \% / \mathrm{sec}$ ずつに区切つて, そ の間の眼振電図より算出し表示してある。したがつて, $180^{\circ} / \mathrm{sec}$ までの視刺㦸負荷時の眼振数を 9 区分して眼 振図より計測し表示してある.

\section{7) 観 察成 績}

正常成人 10 人に拈ける個々の成績は，原則的に相似 ているので, ここでは観察例の 1 人，27 才男子の成績 を述べ，他の観察例については眼振数の変動を表示する にとどめる。

i）視性水平性眼振の観察

視性円筒を右回転すると左へ向から眼振の発来をみる が，円筒回転速度が增すにつれて眼振の 打数を增加す る、眼振の頻度は $100^{\circ} / \mathrm{sec}$ から $140^{\circ} / \mathrm{sec}$ において最

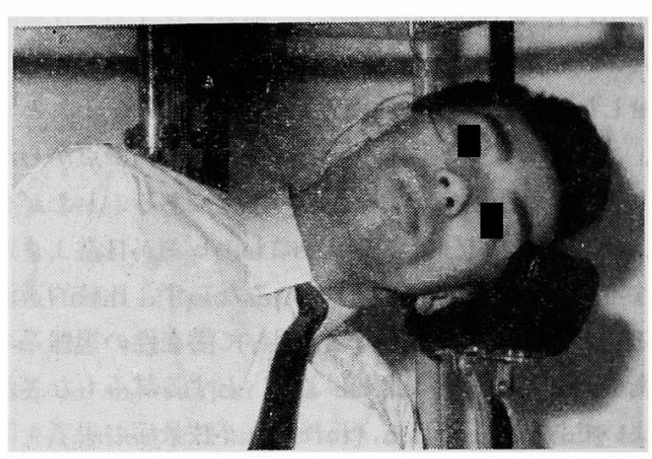

図 3 垂直性眼振の観察（ENG装着）

高となり，20\%/ sec 間に 77 打を認め，160\%/sec をこす とやや減少して $20 \% / \mathrm{sec}$ 間に 65 打を認めた.

次に，円筒を左回転すると右一向かう眼振が生じ, 円 倍回転速度が速くなるにつれて眼振の打数は增加し 120 / sec から $140 \%$ sec に抮いて最大となり 73 打を認める. 160/sec 以後やや眼振は減少し 67 打を認めた.

ii）視性垂直性眼振の観察

a）左傾頭位における観察

円筒を右回転すると眼窩上縁に向から眼振, すなわち 上方への垂直性眼振が生ずる. 眼振は円筒回転速度に従 つて增加し, $80 \%$ sec から $100 \%$ sec に执いて最大となつ て73 打を認め, 以後はほぼ一定となるが, $160 \%$ sec 以 後は娍少しはじめ $160^{\circ} / \mathrm{sec}$ から $180^{\circ} / \mathrm{sec}$ に間に 62 打 を認めた。

次に円筒を左回転すると眼简下縁に向から眼振，すな わち下方への垂直性眼振が生ずる. 眼振は $120^{\circ} / \mathrm{sec}$ か ら $140^{\circ} / \mathrm{sec} に$ に拈い最大となり 82 打を認め以後はやや 減少をはじめ， $160^{\circ} / \mathrm{sec}$ から $180^{\circ} / \mathrm{sec}$ 間に 59 打を認 めた。

b）右傾頭位に打ける観察

円筒を左回枟すると眼窩上縁に向から垂直性眼振を生 ずる.この際上方への眼振は, 円筒回転速度の增加に従 つて眼振打数を增加し， $100 \% / \mathrm{sec}$ から $120 \%$ sec 間にお いて最大となり 69 打を認める. 以後は潮次減少を始め, $160 \%$ sec から $180 \%$ sec 間に 54 打を認める.

円筒を右回転すると，下方への垂直性眼振を生ずる. 円筒回転速度の增加に従つて眼振は增加をはじめ, $100^{\circ}$ 
表 1 視 性 水平性眼振

正 頭 位

\begin{tabular}{|c|c|c|c|c|c|c|c|c|c|c|c|c|}
\hline & & 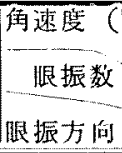 & $\sim$ & ${ }_{40^{\circ}}^{21^{\circ}} \sim$ & ${ }_{60^{\circ}}^{41^{\circ}} \sim$ & $\left|\begin{array}{c}61^{\circ} \\
\sim \\
80^{\circ}\end{array}\right|$ & $\begin{array}{c}81^{\circ} \\
\sim \\
100^{\circ}\end{array}$ & $\mid \begin{array}{c}101^{\circ} \\
\sim \\
120^{\circ}\end{array}$ & $\mid \begin{array}{c}121^{\circ} \\
\sim \\
140^{\circ}\end{array}$ & $\mid \begin{array}{c}141^{\circ} \\
\sim \\
160^{\circ}\end{array}$ & $\begin{array}{c}161^{\circ} \\
\sim \\
180^{\circ}\end{array} \mid$ & $\begin{array}{l}\text { 緿 } \\
\text { 腿 } \\
\text { 振 } \\
\text { 数 }\end{array}$ \\
\hline , & 27 水 & 左 & 30 & 48 & 60 & 68 & 67 & 77 & 77 & 74 & 65 & 566 \\
\hline & 9 & 右 & 36 & 53 & 67 & 69 & 68 & 73 & 75 & 68 & 67 & 576 \\
\hline 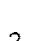 & 32 才 & 左 & 27 & 39 & 54 & 57 & 57 & 54 & 54 & 45 & 54 & 441 \\
\hline 2 & $\delta$ & 右 & 45 & 53 & 60 & 60 & 60 & 61 & 61 & 61 & 60 & 521 \\
\hline 3 & 29 才 & 左 & 29 & 55 & 60 & 72 & 68 & 67 & 49 & 46 & 40 & 486 \\
\hline 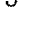 & $\delta$ & 右 & 31 & 60 & 68 & 67 & 65 & 62 & 41 & 27 & 19 & 440 \\
\hline t & 24 才 & 框 & 18 & 48 & 49 & 52 & 66 & 64 & 57 & 55 & 55 & 464 \\
\hline$z$ & $\delta$ & 右 & 18 & 35 & 45 & 55 & 54 & 58 & 53 & 56 & 59 & 433 \\
\hline 5 & 197 & t & 27 & 56 & 69 & 61 & 58 & 57 & 50 & 45 & 45 & 468 \\
\hline 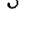 & $\%$ & 右 & 24 & 44 & 65 & 72 & 73 & 74 & 65 & 60 & 55 & 532 \\
\hline 6 & 97 才 & 丞 & 45 & 74 & 79 & 77 & 71 & 65 & 55 & 47 & 32 & 545 \\
\hline & $\hat{0}$ & 右 & 50 & 75 & 74 & 76 & 74 & 81 & 71 & 73 & 66 & 640 \\
\hline 7 & 22 才 & 左 & 24 & 46 & 52 & 60 & 55 & 55 & 42 & 33 & 30 & 397 \\
\hline r & P & 石 & 30 & 46 & 48 & 48 & 35 & 30 & 33 & 34 & 16 & 320 \\
\hline 0 & 25 才 & 応 & 34 & 46 & 57 & 59 & 49 & 55 & 48 & 54 & 53 & 455 \\
\hline & P & 右 & 32 & 52 & 53 & 65 & 63 & 66 & 64 & 53 & 55 & 503 \\
\hline 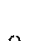 & 25 才 & 在 & 47 & 43 & 58 & 63 & 64 & 66 & 49 & 51 & 48 & 489 \\
\hline 9 & 9 & 右 & 19 & 38 & 54 & 53 & 62 & 70 & 64 & 58 & 51 & 469 \\
\hline 10 & $17 x$ & 在 & 30 & 61 & 67 & 76 & 69 & 59 & 59 & 45 & 45 & 511 \\
\hline 10 & 9 & 在 & 23 & 51 & 59 & 68 & 56 & 58 & 56 & 55 & 55 & 481 \\
\hline
\end{tabular}

$1 \mathrm{sec}$ 以後ほぼ一定となり $20^{\circ} / \mathrm{sec}$ 間に 77 打から 79 打 を認める。

表1，2，3 火は代表例をる含めた 10 人の視性腿振の時 間的推移のありさまを示す 図 4,5,6 は各眼振の分布 図である。これらの表拈よび図沉みられるよらに，各眼

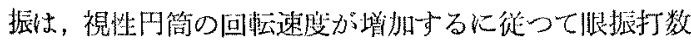
を增加し，40\% $/ \mathrm{sec}$ 加ら $100 \%$ 到 に至り最大となり， 以後やや減少していく，また，䓑直性腿振に技いて，下 向きの画通性腿振が向きのそ机に比しやや発来頻度が 大である.

\section{8）菓却棈円面による棄却挨定 ${ }^{23344)}$}

$1 \% / \mathrm{sec}^{2}$ の角加速度で視性円简を回忶させた際，时成 の経過以伴つて $0^{\circ} / \mathrm{sec} \sim 20^{\circ} / \mathrm{sec}, 21^{\circ} \sim 40^{\circ} / \mathrm{sec}, 41^{\circ} \sim$ $60^{\circ} / \mathrm{sec}, 61^{\circ} \sim 80^{\circ} / \mathrm{sec}, 81^{\circ} \sim 100^{\circ} / \mathrm{sec}, 101^{\circ} \sim 120^{\circ} / \mathrm{sec}$,
图 4 祝性水和性眼振

视址仙湖回忶的速度: $1 \% \mathrm{sec}^{2}$

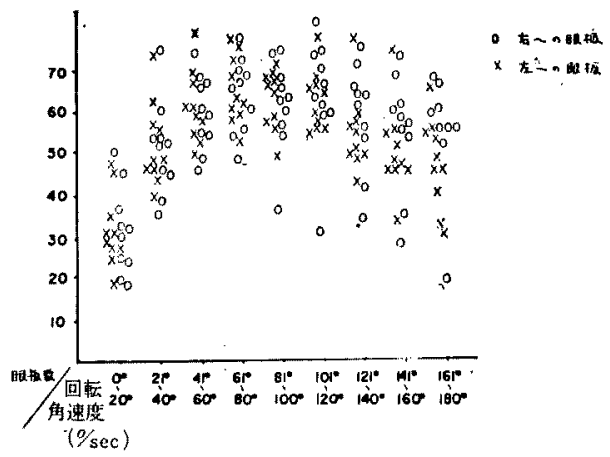


表 2 視 性垂直性眼 振

左 傾 頙 位

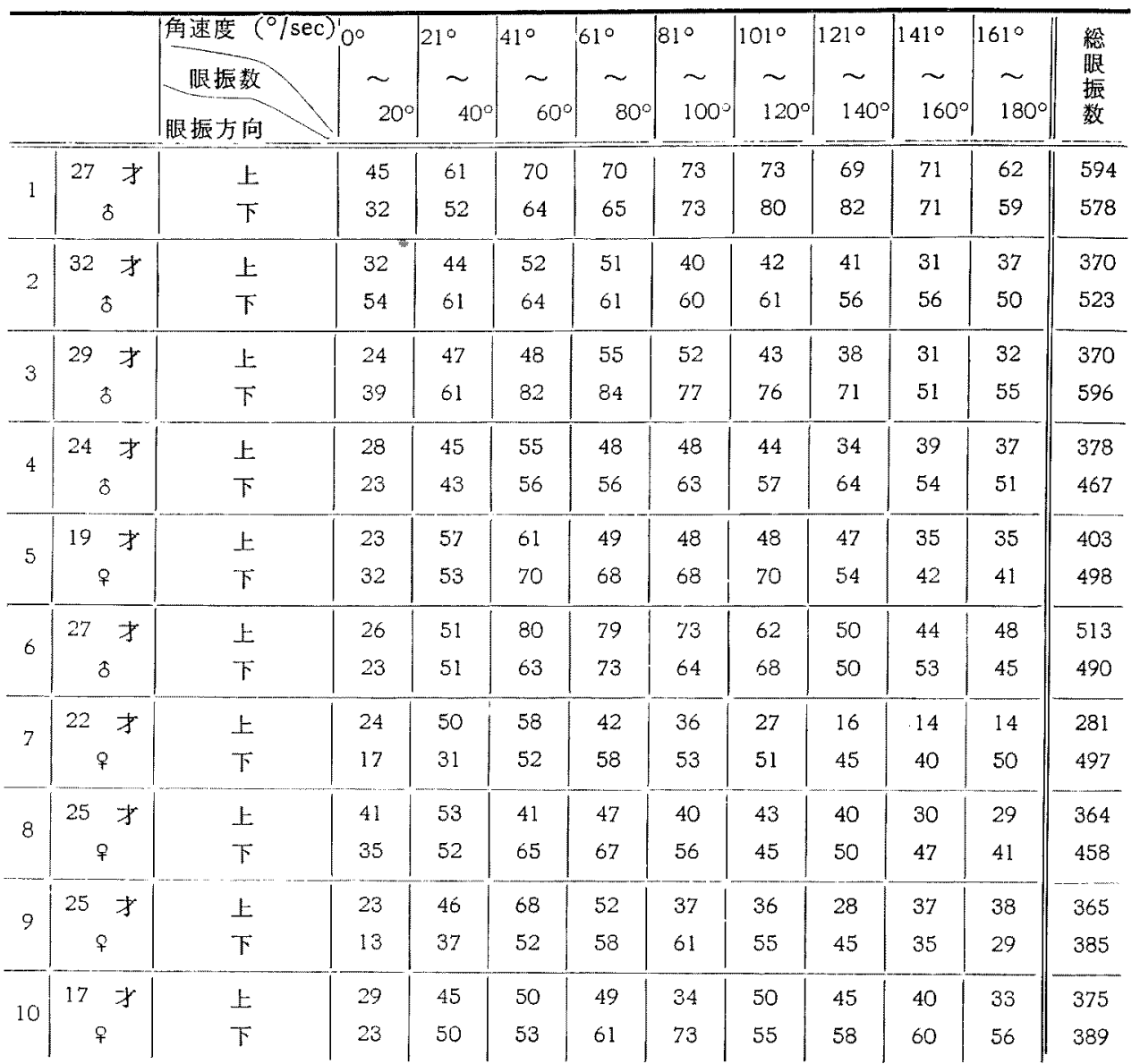

$121^{\circ} \sim 140^{\circ} / \mathrm{sec}, 141 \sim 160^{\circ} / \mathrm{sec}, 161^{\circ} \sim 180^{\circ} / \mathrm{sec} \zeta い 5$ 上うに眼振打数が記録されることは，前述のと括りであ る、各被捡者について得られるこれら9個の值を9次元 ベタトルの直交成分とみなせば，正常人以ついて得られ

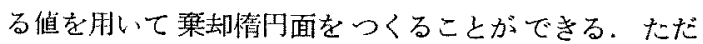
し，夾際には，9次元べトルの解析にはかなりの手数 を要するので，以下述べるように，3次元解析を試み

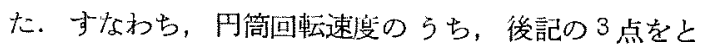
り，支の湘定值を総合したるのを一つの示膘として判断 することにした。

筆者が予倩实験で，視性円筒を種ふなる角速度で等速 回転させて眼振の発来状況をしらべたところ，視性水平 性, 重直性眼振いずれの眼振の発来も, 視性冈筒が $90^{\circ}$

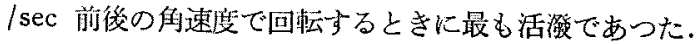

図 5 視性垂直性恨振（上への限振） 視性円䇠回忶角速度：1\%/ $\mathrm{sec}^{2}$

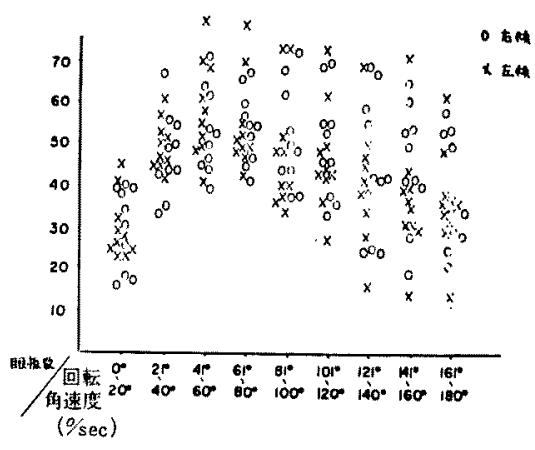


表 3 視性垂直性䀡振

右傾颚位

\begin{tabular}{|c|c|c|c|c|c|c|c|c|c|c|c|c|}
\hline & \multicolumn{2}{|c|}{ 角速度 $(\% / \mathrm{sec}){ }^{\circ}$} & \multirow{2}{*}{$\begin{array}{l}21^{\circ} \\
\sim \\
40^{\circ}\end{array}$} & \multirow{2}{*}{$\begin{array}{l}41^{\circ} \\
\sim 60^{\circ}\end{array}$} & \multirow{2}{*}{$\begin{array}{l}61^{\circ} \\
\sim \\
80^{\circ}\end{array}$} & \multirow{2}{*}{$\begin{array}{l}81^{\circ} \\
\underset{100^{\circ}}{\sim}\end{array}$} & \multirow{2}{*}{$\begin{array}{l}101^{\circ} \\
\sim \\
120^{\circ}\end{array}$} & \multirow{2}{*}{$\begin{array}{c}121^{\circ} \\
\sim \\
140^{\circ}\end{array}$} & \multirow{2}{*}{$\begin{array}{c}141^{\circ} \\
\sim \\
160^{\circ}\end{array}$} & \multirow{2}{*}{$\left|\begin{array}{c}161^{\circ} \\
\sim \\
180^{\circ}\end{array}\right|$} & \multirow{2}{*}{$\begin{array}{l}\text { 総 } \\
\text { 腿 } \\
\text { 脤 } \\
\text { 数 }\end{array}$} \\
\hline & & 眼振方向 & $\sim_{20^{\circ}}$ & & & & & & & & & \\
\hline \multirow{2}{*}{1} & $27 才$ & 上 & 34 & 56 & 54 & 55 & 62 & 69 & 69 & 61 & 54 & 514 \\
\hline & 8 & 下 & 23 & 41 & 63 & 65 & $6 \epsilon$ & 77 & 76 & 79 & 79 & 569 \\
\hline \multirow{2}{*}{2} & 32 才 & 上 & 39 & 44 & 44 & 41 & 37 & 37 & 23 & 19 & 29 & 313 \\
\hline & $\hat{b}$ & 下 & 39 & 51 & 61 & 62 & 66 & 61 & 64 & 51 & 57 & 512 \\
\hline \multirow{2}{*}{3} & 29 才 & 上 & 17 & 43 & 53 & 52 & 48 & 46 & 42 & 42 & 28 & 371 \\
\hline & 古 & 下 & 17 & 45 & 58 & 60 & 62 & 49 & 55 & 55 & 43 & 444 \\
\hline \multirow{2}{*}{4} & 24 才 & 上 & 16 & 35 & 39 & 47 & 50 & 46 & 41 & 41 & 34 & 349 \\
\hline & $\delta$ & 下 & 12 & 31 & 46 & 61 & 53 & 54 & 40 & 45 & 40 & 382 \\
\hline \multirow{2}{*}{5} & 19 才 & 上 & 30 & 54 & 71 & 57 & 44 & 55 & 41 & 53 & 25 & 430 \\
\hline & † & 下 & 18 & 55 & 61 & 66 & 76 & 80 & 66 & 62 & 25 & 509 \\
\hline \multirow{2}{*}{6} & 27 才 & 上 & 39 & 67 & 64 & 60 & 72 & 70 & 68 & 65 & 58 & 563 \\
\hline & $\delta$ & 下 & 18 & 48 & 68 & 71 & 72 & 65 & 68 & 59 & 60 & 529 \\
\hline \multirow{2}{*}{7} & 22 才 & 上 & 38 & $\Delta_{i} 9$ & 50 & 45 & 44 & 33 & 25 & 28 & 21 & 333 \\
\hline & q & 下 & 37 & 58 & 68 & 79 & 67 & 59 & 57 & 36 & 43 & 504 \\
\hline \multirow{2}{*}{8} & $25 才$ & 上 & 40 & 42 & 47 & 66 & 37 & 36 & 25 & 40 & 34 & 369 \\
\hline & ㅇ & 下 & 25 & 38 & 56 & 62 & 60 & 62 & 45 & 39 & 30 & 417 \\
\hline \multirow{2}{*}{9} & $25 才$ & 上 & 25 & 50 & 62 & 67 & 68 & 55 & 59 & 50 & 50 & 486 \\
\hline & 8 & 下 & 16 & 39 & 51 & 56 & 57 & 59 & 48 & 51 & 39 & 416 \\
\hline \multirow{2}{*}{10} & 17 才 & 上 & 18 & 33 & 45 & 55 & 53 & 53 & 55 & 54 & 52 & 418 \\
\hline & † & 下 & 13 & 39 & 48 & 70 & 73 & 64 & 74 & 70 & 62 & 513 \\
\hline
\end{tabular}

回転速度がこ机よりも大きくなつて $180^{\circ} / \mathrm{sec}$ に至ると

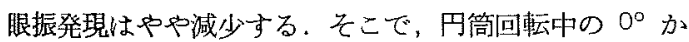
ら $20 \% / \mathrm{sec}$ に括ける眼振頻度, $41 \% / \mathrm{sec}$ から $60^{\circ} / \mathrm{sec}$ に括ける腿振頻度，扣よび $161^{\circ} / \mathrm{sec}$ から $180^{\circ} / \mathrm{sec} に$ 特ける眼振頻度, 計 3 測定値を取り出し, これを 3 次元 ベクトルの直交成分とみなす。

図 4,5,6亿明らかなように，正常成人にみられる水平 性眼振にあつては左，右の回転方向に上る差は認められ

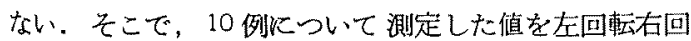
転合算して 20 例として取り扱つた，垂直性眼振の場合 にす，左㑯括上び右傾頭位で上向き眼振や下向き眼振に 差を生ずることはないと考え，上向き眼振は 10 例 20 測 定值とし，下向き眼振むこれ淮じた。

視性水平性眼振を例にとつてみる。すず，水平性眼振
図 6 視性琵速性腿振（下への服振）

視性円簡回転角速度：1\% $\mathrm{sec}^{2}$

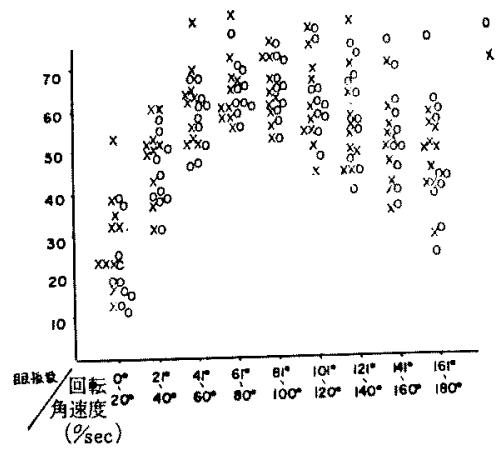


の健康正常人N人について先に選んだる測定値をそれぞ 秋 $\mathrm{x}_{1 \mathrm{i}}, \mathrm{x}_{2 \mathrm{i}}, \mathrm{x}_{3} \mathrm{i}$ (それぞれ $\mathrm{x}_{1}, \mathrm{x}_{2}, \mathrm{x}_{3}$ と略記する) と †る。

$$
\begin{aligned}
& \Sigma \mathrm{x}_{1}=\left(\mathrm{x}_{1 \cdot 1}+\mathrm{x}_{1 \cdot 2}+\mathrm{x}_{1 \cdot 3}+\cdots \cdots+\mathrm{x}_{1 \cdot \mathrm{N}}\right) \\
& \overline{\mathrm{x}}_{1}=\frac{1}{\mathrm{~N}}\left(\mathrm{x}_{1 \cdot 1}+\mathrm{x}_{1 \cdot 2}+\mathrm{x}_{1 \cdot 3}+\cdots \cdots+\mathrm{x}_{1 \cdot \mathrm{N}}\right) \\
& \Sigma \mathrm{x}_{1}^{2}=\left(\mathrm{x}_{1 \cdot 1}^{2}+\mathrm{x}_{1 \cdot 2}^{2}+\mathrm{x}_{1 \cdot 3}^{2}+\cdots \cdots+\mathrm{x}_{1 \cdot \mathrm{N}}^{2}\right)
\end{aligned}
$$

これらに实際の数值をいれると

$$
\begin{gathered}
\Sigma \mathrm{x}_{1}=(30+36+27+\cdots \cdots+23) \\
\overline{\mathrm{x}}_{1}=\frac{1}{20}(30+36+27+\cdots \cdot \cdot+23) \\
\Sigma \mathrm{x}_{1}{ }^{2}=\left(30^{2}+36^{2}+27^{2}+\cdots \cdots+23^{2}\right)(\text { 表 } 1 \text { 至 })
\end{gathered}
$$

となつて，表4に示したよらな結果がえられる。 および $\mathrm{x}_{3}$ についても同様である。

表 $4 \mathrm{x}_{1}, \mathrm{x}_{2}$ 招よび $\mathrm{x}_{3}$ の和，平均拈よび平方和

\begin{tabular}{c|r|r|r}
\hline & \multicolumn{1}{|c|}{$\mathrm{x}_{\mathbf{1}}$} & \multicolumn{1}{c|}{$\mathrm{x}_{\mathbf{2}}$} & \multicolumn{1}{c}{$\mathrm{x}_{\mathbf{3}}$} \\
\hline$\Sigma \mathbf{x}$ & 619 & 1198 & 970 \\
$\overline{\mathbf{x}}$ & 30.95 & 59.90 & 48.50 \\
$\Sigma \mathrm{x}^{2}$ & 20885 & 73274 & 51072
\end{tabular}

举却梋円面の方程式は

$$
\mathrm{F}_{0}=\frac{(\mathrm{N}-\mathrm{k}) \mathrm{N}}{(\mathrm{N}+1) \mathrm{k}} \sum_{\alpha=1}^{\mathrm{k}} \sum_{\beta=1}^{\mathrm{k}} \cdot \psi_{a \beta}
$$

で表わされる。いまの例では

$$
\mathrm{N}=20 \quad \mathrm{k}=3 \text { である. }
$$

$\psi_{\alpha \beta} は$

$$
\phi_{a \beta}=\Sigma \mathrm{x}_{\alpha} \mathrm{x}_{\beta}-\frac{\Sigma \mathrm{x}_{\alpha} \sum \mathrm{x}_{\beta}}{\mathrm{N}}
$$

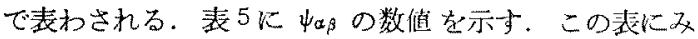

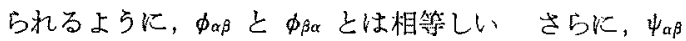
を求めるための9個の方程式からなる連立方程式心，そ の特徽を利用して表 6 の上5に表和すことがでさる，裴 中，A，B，Cそれぞれが3つの方程式を表わしている。 すなわり，A についてみると

$r=1$ K対しては $1726.95 \psi_{11}+950.9 \psi_{21}+176.5 \psi_{31}=1$ $r=2$ に対しては $1726.95 \psi_{12}+950.9 \psi_{22}+176.5 \psi_{32}=0$ $r=3$ に対しては $1726.95 \psi_{12}+950.9 \psi_{23}+176.5 \psi_{33}=0$ を表わしているのである，B，CKつい炕す同様である。 A, B , C すなわち 9 個の末知数 $\psi_{11}, \psi_{12}, \psi_{13}, \cdots \cdots \psi_{33}$ を 含む連立厅程式は，消去法によつて逐次米知数の数を娍 らすことによつて解くことができる，その過程を略記し て表7に示す
表 $5 \phi_{\alpha \beta}$ の值

$$
\begin{aligned}
& \phi_{11}=20885-\frac{619^{2}}{20}=1726.95 \\
& \phi_{12}=\phi_{21}=38029-\frac{619 \times 1198}{20}=950.9 \\
& \phi_{13}=\phi_{31}=30198-\frac{619 \times 970}{20}=176.5 \\
& \phi_{22}=73274-\frac{11982}{20}=1513.8 \\
& \phi_{23}=\phi_{32}=58101-\frac{1198 \times 970}{20}=-2 \\
& \phi_{33}=51072-\frac{970^{2}}{20}=4027
\end{aligned}
$$

表 $6 \psi_{x \beta}$ を求めるための連站方程式の係数

\begin{tabular}{r|r|r|r|r|r|r}
\hline & \multicolumn{1}{|c|}{$\psi_{1_{\gamma}}$} & \multicolumn{1}{|c|}{$\psi_{2_{\gamma}}$} & \multicolumn{1}{c|}{$\psi_{3 \gamma}$} & $\gamma=1$ & $\gamma=2$ & $\gamma=3$ \\
\hline $\mathrm{A}$ & 1726.95 & 950.9 & 176.5 & 1 & 0 & 0 \\
$\mathrm{~B}$ & 950.9 & 1513.8 & -2 & 0 & 1 & 0 \\
$\mathrm{C}$ & 176.5 & -2 & 4027 & 0 & 0 & 1
\end{tabular}

$\mathrm{A}^{\prime}, \mathrm{B}^{\prime}, \mathrm{C}^{\prime}$ は A，B，C をそれそれ $\psi_{1 \gamma}$ の係数で割つ て得たものであつて，これKより $\mathrm{A}, \mathrm{B}, \mathrm{C}$ は小ずれる 将の係数が 1 である方程式に彗き直されたことになる。

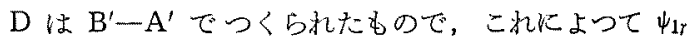

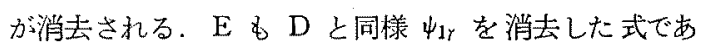
る、D，E加らそれでれ $\mathrm{D}^{\prime} ， \mathrm{E}^{\prime}$ をつくつて $\psi_{2 r}$ の係数 をはに直し $\mathrm{D}^{\prime}-\mathrm{E}^{\prime} て ゙ \psi_{r}$ を消去したものが $\mathrm{F}$ 、これを

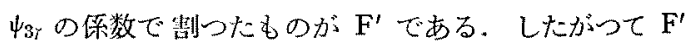
から䌾ら

$$
\begin{aligned}
& \psi_{31}=-0,0000394 \\
& \psi_{32}=0,0000250 \\
& \psi_{33}=0,0002501
\end{aligned}
$$

が得られる。これを $\mathrm{E}^{\prime}$ に入れて

$$
\psi_{21}=-\{(-14.23190) \times(-0.000394)\}=-0.0005607
$$
扰よび

$$
\begin{array}{r}
\psi_{\underline{2}}=-(-14.23190 \times 0.0000250+0.0006559) \\
=0.0010117
\end{array}
$$

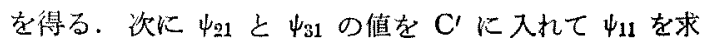
めることがでさる。

$$
\begin{aligned}
\psi_{11} & =0.01133 \times(-0.005607)-22.81586 \times(-0.0000394) \\
& =0.0008926
\end{aligned}
$$

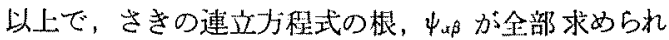

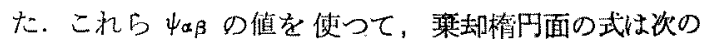
よらに裴わされる。 
表 7 麦 6 の連立方程式

\begin{tabular}{|c|c|c|c|c|c|c|}
\hline & $\psi_{1_{\tau}}$ & $\psi_{3 \gamma}$ & $\psi_{3}$ & $r=1$ & $r=2$ & $r=3$ \\
\hline A & 1726.95 & 950.9 & 176.5 & 1 & 0 & 0 \\
\hline $\mathrm{A}^{\prime}$ & 1 & 0.5506239 & 0.1022033 & 0.0005791 & 0 & 0 \\
\hline B & 950.9 & 1513.8 & -2 & 0 & 1 & 0 \\
\hline $\mathrm{B}^{\prime}$ & 1 & 1.5919655 & -0.0021033 & 0 & 0.0010516 & 0 \\
\hline $\mathrm{C}$ & 176.5 & -2 & 4027 & 0 & 0 & 1 \\
\hline $\mathrm{C}^{\prime}$ & 1 & -0.0113314 & 22,8158640 & 0 & 0 & 0.0056657 \\
\hline $\mathrm{D}=\mathrm{B}^{\prime}-\mathrm{A}^{\prime}$ & & 1.0413416 & -0.1043066 & -0.0005791 & 0.0010516 & 0 \\
\hline $\mathrm{D}^{\prime}$ & & 1 & -0.1001656 & -0.0005561 & 0.0010099 & 0 \\
\hline$E=B^{\prime}-C^{\prime}$ & & 1.6032969 & -22.8179673 & 0 & 0.0010516 & -0.0056657 \\
\hline$E^{\prime}$ & & 1 & -14.2319038 & 0 & 0.0006559 & -0.0035338 \\
\hline $\mathrm{F}=\mathrm{D}^{\prime}-\mathrm{E}^{\prime}$ & & & 14.1317382 & -0.0005561 & 0.0003539 & 0.0035338 \\
\hline $\mathrm{F}^{\prime}$ & & & 1 & -0.0000394 & 0.0000250 & 0.0002501 \\
\hline
\end{tabular}

$\frac{(20-3) \times 20}{3 \times(20+1)}\left\{0.000893\left(x_{1}-30.95\right)^{2}+0.001012\left(x_{2}-\right.\right.$ $59.90)^{2}+0.000250\left(x_{3}-48.50\right)^{2}-2 \times 0.000561\left(x_{1}-\right.$ $30.95)\left(x_{2}-59.90\right)-2 \times 0.000039\left(x_{1}-30.95\right)\left(x_{3}-\right.$ $\left.48.50)+2 \times 0.000025\left(x_{2}-59.90\right)\left(x_{3}-48.50\right)\right\}=$

$\mathrm{F}_{20-3}^{3}(0,05)=3.1968$

さらに整理して表8の最上段に掲げる式が得られる。

任意の被険者について視性水平性眼振をしらべて得た 3 つの測定值 $\mathrm{x}_{1}, \mathrm{x}_{2}, \mathrm{x}_{3}$ をこの式の左辺に代入して得ら れた值が1より大きい場合には，この水平性眼振は危險 率 $5 \%$ で正常でないと判定することがでさる．上述の解

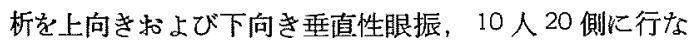
いそれぞれ表 8 に示寸上らな裹却棈円面の式が得られ
万.

\section{9) 症例}

以上得られた式を用いて一症例を検討してみる。 症例 $\mathrm{O}$ 沢○二 347 才

現病歴昭和 38 年9 月 2 日，交通事故で右側頭部受 傷（荒木分類 N 型），受傷後軽度の立ちくらみを訴点る。

現症 (受傷 4 力月後)

耳舆鏡検查に著変はない。

平価機能檢査

i) 立直り検查 両脚直立 $(-)$, 単脚直立 $(+)$, Mann's Test $(+)$ ii) 编倚检 查 特発性眼振 (一)

表 8 筱却松円面の方程式

\begin{tabular}{|c|c|}
\hline & 萁却棈円面の方程式（危險率 $5 \%$ ） \\
\hline 水平性腿振 & $\begin{array}{l}0.00151\left(x_{1}-30.95\right)^{2}+0.00171\left(x_{2}-59.9\right)^{2}+0.00042\left(x_{3}-48.5\right)^{2} \\
-0.00189\left(x_{1}-30.95\right)\left(x_{2}-59.9\right)+0.00084\left(x_{2}-59.9\right)\left(x_{3}-48.5\right) \\
-0.00013\left(x_{3}-48.5\right)\left(x_{1}-30.95\right)=1\end{array}$ \\
\hline $\begin{array}{l}\text { 上向き } \\
\text { 妻直珄眼振 }\end{array}$ & $\begin{array}{l}0.00243\left(x_{1}-30.05\right)^{2}+0.000098\left(x_{2}-55.6\right)^{2}+0.00064\left(x_{3}-37.5\right)^{2} \\
+0.00119\left(x_{1}-30.05\right)\left(x_{2}-55.6\right)-0.00059\left(x_{2}-55.6\right)\left(x_{3}-37.5\right) \\
-0.000035\left(x_{3}-37.5\right)\left(x_{1}-30.05\right)=1\end{array}$ \\
\hline $\begin{array}{l}\text { 下向き } \\
\text { 画值珄腿振 }\end{array}$ & $\begin{array}{l}0.00128\left(x_{1}-25.45\right)^{2}+0.00778\left(x_{2}-60.05\right)^{2}+0.00056\left(x_{3}-47.75\right)^{2} \\
-0.00216\left(x_{1}-25.45\right)\left(x_{2}-60.05\right)-.0 .00024\left(x_{2}-60.05\right)\left(x_{3}-47.75\right) \\
-0.00009(x-47.75)\left(x_{1}-25.45\right)=1\end{array}$ \\
\hline
\end{tabular}


表 9 症 例 ○沢○二の視性眼振検査成紋

\begin{tabular}{|c|c|c|c|c|c|c|c|c|c|c|c|}
\hline \multicolumn{3}{|c|}{$\begin{array}{l}\text { 角速度 }\left({ }^{\circ} / \mathrm{sec}\right) \\
\text { 眼振方向 } \\
\text { 榆查方法 }\end{array}$} & $\begin{array}{l}0^{\circ} \\
\quad \sim 20^{\circ}\end{array}$ & $\begin{array}{l}21^{\circ} \\
\quad \sim \\
\quad 40^{\circ}\end{array}$ & $\begin{array}{l}41^{\circ} \\
\sim \\
\quad 60^{\circ}\end{array}$ & $\begin{array}{l}61^{\circ} \\
\quad \sim \\
\quad 80^{\circ}\end{array}$ & $\begin{array}{l}81^{\circ} \\
\sim \\
100^{\circ}\end{array}$ & $\mid \begin{array}{c}101^{\circ} \\
\sim \\
120^{\circ}\end{array}$ & $\mid \begin{array}{c}121^{\circ} \\
\sim \\
140^{\circ}\end{array}$ & $\mid \begin{array}{c}141^{\circ} \\
\sim \\
160^{\circ}\end{array}$ & ${ }^{161^{\circ}} \begin{array}{r}\sim \\
\\
180^{\circ}\end{array}$ \\
\hline \multirow{2}{*}{\multicolumn{2}{|c|}{ 水平性眼振 }} & tr & 22 & 51 & 62 & 58 & 50 & 48 & 48 & 45 & 44 \\
\hline & & 右 & 31 & 47 & 61 & 61 & 59 & 53 & 52 & 43 & 48 \\
\hline \multirow{4}{*}{$\begin{array}{l}\text { 重 } \\
\text { 直 } \\
\text { 性 } \\
\text { 腿 } \\
\text { 振 }\end{array}$} & \multirow[b]{2}{*}{ 左傾頭位 } & 上 & 25 & 49 & 51 & 47 & 38 & 47 & 35 & 19 & 18 \\
\hline & & 下 & 23 & 39 & 38 & 42 & 21 & 0 & 2 & 0 & 0 \\
\hline & \multirow{2}{*}{ 右傾䫒位 } & 上 & 10 & 22 & 6 & 2 & 0 & 0 & 0 & 0 & 0 \\
\hline & & 下 & 26 & 42 & 40 & 44 & 38 & 42 & 28 & 30 & 22 \\
\hline
\end{tabular}

頭位性眼振 (十) directional changing form 遮眼書字検查 右への規則型偏書:

足踏検楂 軽度の Ataxia 至伴う左への偏倚

iii) 実験的眼振検查

Caloric Test 左側 CP

視性眼振検查 表9 亿示可.

表 9 の 3 点 $\mathrm{x}_{1}, \mathrm{x}_{2}, \mathrm{x}_{3}\left(0^{\circ} \mathrm{sec} \sim 20^{\circ} / \mathrm{sec}, 41^{\circ} / \mathrm{sec} \sim 60^{\circ}\right.$ $\left(\mathrm{sec}, 161^{\circ} \mathrm{sec} \sim 180^{\circ} / \mathrm{sec}\right)$ 芫取り出し 8) で得られた表 8 の式に代入する.

○水平性眼振（左への眼振）

$0.00151(22-30.95)^{2}+0.00171(62-59.9)^{2}+0.00042$ $(44-48.5)^{2}-0.00189(22-30.95)(62-59.9)+$

$0.00084(62-59.9)(44-48.5)-0.00013(22-30.95)$ $(44-48.5)=0.15$

この上5に，左へ向から水平性眼振は 0.15 と1より 小さいから，萁却することはできない，すなわち，異常 であるとはみなしえない，右へ向から水平性眼振につい ても同様に 3 点を代入して次のごとき結果が得られる.

右への水平性眼振 $\quad 0.001$

(○垂直性眼振

$\begin{array}{ccc}\text { 左傾頭位 } & \text { 上方への眼振 } & 0.26 \\ & \text { 下方への眼振 } & 4.68 \\ \text { 右傾頭位 } & \text { 上万八の眼振 } & 4.08 \\ & \text { 下方への眼振 } & 3.24\end{array}$

この数値より, 本症例の視性眼振は水互性眼振心正常 域内にあるが，垂䣫性眼㧓，特に右傾頭位の場合，上方 への眼振および下方への眼振共に正常域を越えているこ とがわかる。

\section{0) 考案}

冒頭で述べたように，視性眼振は一種の平衡反射であ る。したがつて，この眼振を指標としてヒトの平衡機能
を检出しようとする試みは充分なされてよいと思う。と ころで，これまでの検査で視性眼振が湘定される場合， 多くは水平性眼振の検查にとどまり，垂直性眼振の齐統 的検查を欠いていた。 また，この検查を眩暴，平衡失調 症例の平衡機能検査に応用するには，正確な推計学的処 理を久いていたため，多くの不倩をまぬがれなからた。

筆者りは，すでに報告したよらに，とト扰よび動物を 対象とする実験成績より，視性眼反射永平性眼振扣よ び垂直性眼振共に测定することが窒ましいことそして 視刺㦸を与える場合は，円筒を等速回転するよりは加速 回転して視性眼振の発来の変化を観察することが異常の 检出方法としてはすぐれていることを知つた、この点を 考慮して，上述したよらに，視性眼反射を水平性ならび に垂值性眼振で検索し，かつ，加速度視刺战を採用乙 た、ちなみに，筆者が視刺焷負荷装置として視性大円简 を選んた理由は，この方法では被検者の視野全体に刺㦸 が加わり，従来の小型視性ドラムでは得られない強い視 刺㦸が得られるので，より高率に潜在性平衡失調を检出 しうることにあつた。

この検查法で問題となるのは，垂直性腿振の検査を斜 傾頭位で行なつている点あるう，この点心今後に多くの 問題点を残していることを否定はしない，この姿勢で は，頸反射，迷路反射（前庭耳石系）が加わるほか，頸 部の諸器管に血管 (頸椎動脈) の形態異常か゚もたらされ る可能性があり，また，この頭位では，頭蓋内の循環障 㕩が葱起される恐れがある、検查時，これら視刺战以外 の多くの因子が加わつている点が問題となる.

然し，この事肃は，立場を変えてみると，大きな意味 をるつるのと思う，正常人や正常動物にあつては，視 器, 迷路, 頸部, 頸部深部受容器が亘に密なる連関を有 することは、これまでにも報告があるが，最近教室の寺 
山牥がより詳細な動物実験を行なつて証明している。た とえば，上述の方法で頸部を右または左に傾斜するとす れば，前庭耳石采は刺战され，これかららのインバルスは 視刺战と合して，正常頭位での視性反射とは巽なつた視 性反射を産むであるう．特にこの際，この顕位で異常な 迷路性インパルスが生し，これが視性反射に分入する場 合には，正常頭位では認められぬ異常な視性眼振が生ず る可能性を充分にるつている．しかしてこの際，視性反 射と頸部反射との間にもこれと類似した関係の成立する ことを否定できないすなわち，かかる姿勢強制して 視性垂直性腿振を検查することは，できるだけ単純な条 件下に一つの平衡器を刺㦸して，その際の反射を测定 し、これにてとトや動物の平衡機能を考察しょうとする 方針とは全く逆である。しかし，ヒトや動物の平衡が視 器, 迷路、深部受容器等の密なる連関のもとに円䇏に保 たれている事笑より考学ると，積極的に迷路反射か涇頁反 射等を介入させ，その際の視性平衡を湘定し，軽微な平 衡失調を明膫に表明し上らとする万法もとつてよいので はあるまいか？

いずれの検查方針で行なつた方が上りよい效果をあげ

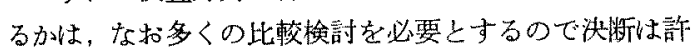
されないしかし，上述の方法で，扐扐れは従来の視 性眼振検查では得られない高率の異常を表出し得ている ことは事実であり，また，この方法で得られた特異な処 見が病巣の鑑別䛦断行役立ちうることもしばしばあるこ とを経験している。

特わりに，この論文で採用した統計的処理法，ならび にその成果について記す，前項 8) に記載した解析の前 提として，各時点に括ける正常成人 10 人の眼振数が正 規分布をしていることが必要である。表 1,2拉よび3に みら机ように，いずれの眼振にあつても，各時点にお ける眼振数は，それぞれの平㚬值上りも大きいものと， それよりも小さいむのとが，汪添同じ例数ずつみられ る.すなわち，各時点に扔ける眼振数が扣おむ标正規分 布している，との仮定を否定することはできない．

正常人について得られた值を用いて， $0^{\circ} \sim 20^{\circ} / \mathrm{sec} K$

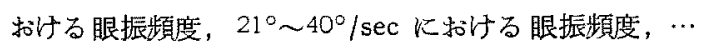
‥,というように, 個々の時点ごとに, 眼振頻度の平均 値、正常筙围，あるいは，寁却限界を定めることは，む ちろん容易である.しかし，このよらにして，個々の时 点ごとに眼振頻度の萧却限界を定めたとしても，その毫 却限界は，ある患者の腿振の現われ万が正常人と異なつ ているか否かの判断には，理論上も実際上もほとんど役
立たない。

わたくしたちが，ある患者の眼振の現われ方を観察し て，その結果が正常であるか否かを判断する場合には， $0^{\circ} \sim 20^{\circ} / \mathrm{sec}$ K怙ける眼振頻度, $21^{\circ} \sim 40^{\circ} / \mathrm{sec}$ に拈け 当眼振覑度，…… $161^{\circ} / \mathrm{sec} \sim 180^{\circ} / \mathrm{sec}$ K扣ける眼振頻 度，というょうに，9個の值を全体としてみているので あつて，個々の值だけをみているのではないからであ る.9 個の値を9 次元べクト儿直交成分とみなして裹 却粉円面を定めることも可能であり，かつ，理論的には 妥当である、しかし，この上うにして得られる㻭却梋円 面の方程式の項数は， $\left(\mathrm{x}_{1}-\overline{\mathrm{x}}_{1}\right),\left(\mathrm{x}_{2}-\overline{\mathrm{x}}_{2}\right), \cdots\left(\mathrm{x}_{9}-\overline{\mathrm{x}}_{0}\right)$, の各偏差の平方の項が9項，および，これらの偏差 9 個 のうちから2個ずつをとつて乘じた項が 36 項, 計 45 項 にも達するものとなる。かかる多項式は，実用に適しな いであろう。

得られる集却棈门面の方程式とし.ては，䨋用上の目的 からはななるへく項数の少ないものが望むしいここ で, 眼振頉度 。 $21^{\circ} \sim 40^{\circ} / \mathrm{sec}(t=30), 41^{\circ} \sim 60^{\circ} / \mathrm{sec}(t=50)$ と大きく なり，雨後ふたたび小さくなつている，xを $\mathrm{t}$ の函数 $f(t) \varepsilon し, か り$,

$$
\mathrm{x}=\mathrm{f}(\mathrm{t})=\mathrm{a}+\mathrm{+}+\mathrm{bt}+\mathrm{ct} \mathrm{t}^{2}+\cdots \cdots
$$

で表劣せるものとすれば，少なくともはじめの3 項は省 略することができない、また，逆に， $0^{\circ} \sim 20^{\circ} / \mathrm{sec}$ ，およ び $161^{\circ} \sim 180^{\circ} / \mathrm{sec}$ で小さく，中間で大きい值をとる $\mathrm{x}=\mathrm{f}(\mathrm{t})$ の曲線は，近似的には

$$
\mathrm{x}=\mathrm{a}+\mathrm{bt}+\mathrm{ct}^{2}
$$

なる放物線の一部とみなすことができる。この放物線の 式の係数 $\mathrm{a}, \mathrm{b}$ 打よび c を決定するために必要にして 充分な条体は， $\mathbf{t} か ゙ \mathrm{t}_{1}, \mathrm{t}_{2}$ 木たは $\mathrm{t}_{3} な る$ 值をとると きの $\mathrm{x}$ の值 $\mathrm{x}_{1}, \mathrm{x}_{2}, \mathrm{x}_{3}$ が与兄られることである。

かかる根拠に基ついて，前項 8)に述べたよらなる次 元解析を行なつたのであつた。 そして輩8に示したよら に, 各6 項よりなる集却棛円の方程式を得た。この式が 眼握の䛦断に有用なことは，前項9)で実例について示 したとおりである。

\section{1) むすひ}

迷路機能に異常を認めない正常成人10人対象とし， これに水平性，上向きまたは下向き垂直性視刺战を負荷 した場合の眼振を記録観察した。

この観察結果飞基づいて，視性水汗性腿振，上向き乘 直性眼振抽よび下向き垂直性眼振に刘する兖却棛円面の 方程式を導いた。この式が，患者について視性眼振を検 
查した場合，ての眼振が正常であるか否かの判定に有用

であることを示した。

\section{立献}

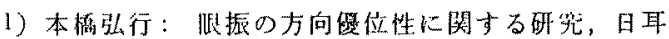
鼻， $68,18,1965.2$ 2) 統計科学研究会編: 新編統計

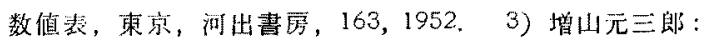

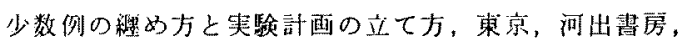
54, 1949.4) 學居饭婎他: 医学・生物学のたdの推 計学, 東京, 菄索大学䏣版会, $55,1954,5)$ 寺山邦 昭：視器，迷路と頙筋項筋の自己受容器，日耳鼠，67,
$1066,1964$.

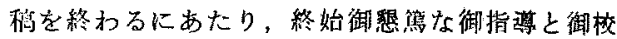

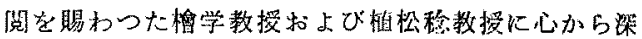
謝すると共に，種々御助霄をいただいた北原正章助 教授ならびに教室員各位に御礼申し上げます

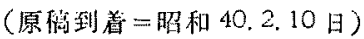

